DOI : $10.14746 / p p \cdot 2014.19 .4 .7$

Magdalena MUSIAŁ-KARG

Poznan

\title{
The use of e-voting as a new tool of e-participation in modern democracies
}

\begin{abstract}
Finding the answer to the question of the role of electronic voting in a modern country constitutes an important part of researches into electronic democracy. The recent dynamic development of information and communication technologies (ICT) and mass media have been leading to noticeable changes in functioning of contemporary countries and societies. ICT is beginning to play a greater and greater role and filter down to almost every field of contemporary human life - including politics. Electronic voting represents one of the more and more popular forms of so called e-democracy, and is an interesting research subject in the context of mechanisms for implementing this form of participation in elections, its legitimization, specific technological solutions for e-voting and their effectiveness as well as unintended consequences. The main subject of this text is the use of electronic voting (e-voting) as one of the forms of electronic democracy. The article attempts to answer the following research questions: First, what is the impact of ICT on the political processes - particularly on the voting procedures? Secondly, what is the essence of electronic voting and what are its main features? Finally, what are the e-voting experiences in the European countries?

The text is devoted rather to general remarks on e-voting, and does not constitute a complete analysis of the issue. It is intended to be a contribution to the further considerations.
\end{abstract}

Key words: e-voting, electronic voting, e-democracy, ICT

$\mathbf{F}$ inding the answer to the question about the role of electronic voting in a modern country constitutes an important part of researches into electronic democracy, which have been adopting various forms till now (e.g. teledemocracy). Since its emergence in 1990s, the concept of e-democracy has been perceived as a proof of changes that occurred in the paradigm of democratic means of exercising power. According to the opinions of those who support application of information and communication technologies into political life, the contemporary civilization faces the era of electronic democracy that is based on modern ICT tools and constitutes a new method of exercising democratic power.

The second half of $19^{\text {th }}$ century and the following years stood for rapid development of various tools based on electricity. The development of telecommunication (telephone, telegraph) and progress of electronic media - mainly radio and television (which according to Marshall MacLuhan introduced the human civilization into times of global village) constitute important elements of this period. Currently, in the face of the so-called era of computers and the Internet, we are now living in times of "history in the making" (Gawrysiak, 2008, p. 8), which is related to so-called information revolution (Keohane, Nye, 1999, p. 200). Easy access to information (being a consequence of development of the Internet, television and mobile communications) affects millions of people in the world, and also changes rules of social life in a broader perspective (Porębski, 2004, p. 9). 
The dynamic development of modern technology leads to noticeable changes in functioning of contemporary countries and societies, and as a result of these changes ICT has begun to play greater role and filter down to almost every field of contemporary human life - also politics.

The political institutions, political parties and politicians use ICT in three main processes in the political market, namely in information, communication and voting procedures. The main subject of this text is to analyze the use of electronic voting (e-voting) as one of the forms of electronic democracy. The article attempts to answer the following research questions: First, what is the impact of ICT on the political processes in the political market - particularly on the voting procedures? Secondly, what is the essence of electronic voting and what are its main features? Finally, what are the e-voting experiences in the European countries? The text is devoted rather to general remarks on e-voting, and does not constitute a complete analysis of the issue. It is intended to be a contribution to the further considerations.

\section{Research context}

The researches into problems connected with e-voting are gaining significance because increasingly more and more countries in Europe and across the world are analyzing issues concerning the possibilities of implementing new, electronic methods of voting: e.g. through the Internet or mobile services. Consequently, the terms: e-democracy, e-participation and e-voting most frequently arise in the context of this research.

Undoubtedly, electronic democracy, electronic participation and electronic voting are more and more frequently becoming the leading subjects of scholarly inquiries, which is particularly visible in the researches of the West. The problems connected with electronic democracy and its forms or instruments have been addressed for a dozen or so years by Graeme Browning (2005), Lawrence K. Grossman (1995), Rosa Tsagarousianou (1999, 2000), Barry N. Hague, Brian Loader (1999), Robert Krimmer (2006, 2008), Alexander H. Trechsel (2007). However, it should be mentioned that the authors depend mostly on the examples of applying ICT and e-voting into political space of the USA and they pay significantly less attention to the analysis of consequences that e-voting has for the European plane.

It should be also added that - when considering e-voting in Europe - the largest number of researches on e-voting in Europe concern Estonia (authors: Ülle Mädise (2006), Wolfgang Drechsler (2006)) and Switzerland (authors: Nadja Braun (2006), Alexander H. Trechsel $(2002,2007)$ etc.), i.e. the countries which implemented e-voting at least several years ago.

It should be emphasized that the influence of ICT on democracy has been becoming an increasingly popular research subject also in Poland over the last years. Researchers who undertake this subject are e.g. Leszek Porębski (2004, 2012), Maria Marczewska-Rytko (2002, 2010), Magdalena Musiał-Karg (2010, 2011, 2012), Daniel Mider (2008), Mirosław Lakomy (2013), Przemysław Maj (2009), Andrzej Kaczmarczyk (2010). In spite of the increasing number of researches into how new technologies affect democracy, there is still a shortage of comprehensive researches in Poland and abroad 
into the problems of electronic voting, particularly its determinants, possibilities of implementation, barriers, chances to succeed, effectiveness, etc., which are based on examples of European countries, that introduced this new form of e-participation, or due to different shortcomings - have resigned from its implementation.

Thus, electronic voting is an interesting research subject in the context of mechanisms for implementing this form of participation in elections, its legitimization, specific technological solutions for e-voting and their effectiveness as well as unintended consequences (i.e. impact on the importance of traditional methods of voting). The problem addressed in this work has not yet been as comprehensively analyzed in Poland as it is planned within this undertaking.

\section{E-democracy and e-participation}

Taking into account the impact of the Internet on political life, it is crucial that ICT (including the Internet) allow overcoming barriers connected with the actual remoteness of voters to those who govern or represent the governing. Undoubtedly, the application of electronic techniques into democracy is a revolution. However, it is worth having in mind that despite the speedy development of ICT, technical problems and e.g. mental limitations may stretch the process of intensification of ICT application to a dozen or so years (especially in less developed countries). What is more, the rapid development of the Internet influences contemporary civilization, hence changing the character of interpersonal relationships, way of communication, going in for politics and contributes to creation of a new quality of social life.

The Internet has become a tool for politics. The role of ICT gained such an importance that some theoreticians of democracy see the necessity of changing the paradigm of understanding the democratic system (Hague, Loader, 1999) and introducing a notion of electronic democracy. There is no agreement in social studies how to understand this term, thus there is no uniform definition. Nevertheless, it is worth presenting a couple of definitions, which seem to be the most distinctive and accurate for the proper understanding of the term electronic democracy. According to Martin Hagen, "an Electronic Democracy is any democratic political system in which computers and computer networks are used to carry out crucial functions of the democratic process - such as information and communication, interest articulation and aggregation, and decision-making (both deliberation and voting)" (Hagen, 1997). Hagen distinguishes between three various concepts of electronic democracy: teledemocracy, cyberdemocracy and electronic democracy.

Teledemocracy is the oldest concept of electronic democracy developed in the 1970s. It was designed to introduce additional forms of direct democracy within the American political system and implement them through using new communication technologies. The main goal of teledemocracy is to establish more direct democratic forms within political system by using the new communication technologies. Whereas the concept of teledemocracy emerged as a result of the cable television development, cyberdemocracy based on the evolution of computer networks. Unlike teledemocracy and cyberdemocracy, electronic democratization does not aim at establishing direct forms of democracy but at improving the representative democracy (Hagen, 1997). Electronic democratiza- 


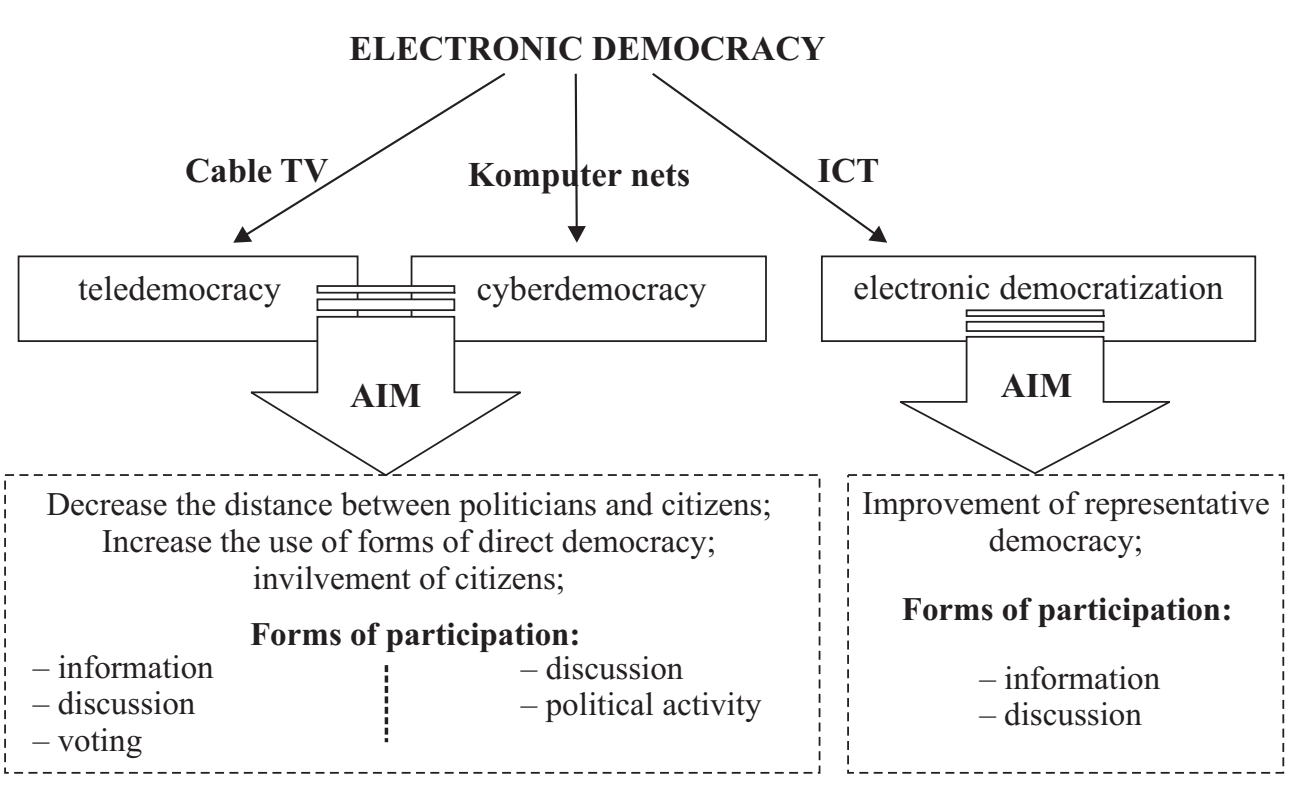

Diagram 1. Hagen's concepts of electronic democracy

Source: The current author's study based on: Hagen, 1997.

tion is defined as a form of development and reinforcement of democracy, which uses new communication technologies to strengthen political power of those who are often omitted in the most important political processes (Hacker, Toino, 1996, p. 72). The Electronic democratization supports the development of representative forms of democracy and emphasizes the value of information exchanges and political discussions for the citizens' involvement in the political sphere. The concept has been crucial in the implementation of many political uses of computer networks today, especially in the area of political information systems.

According to this approach, Internet democracy is similar or identical with cyberdemocracy. The issues connected with electronic democracy are discussed by Polish scholars (e.g. Grabowska, Szawiel, Kaczmarczyk, Sakowicz and others). According to one of the most detailed definition presented by Andrzej Kaczmarczyk and Roman Czajkowski, electronic democracy is understood as a set of processes that are realized through electronic media from the beginning of a civil concept and the formulation of suggestions until their final implementation. This set comprises researching activities, planning, implementation and management (making decisions, taking control, information, communication and more). The authors claim that information society would create a new model of democracy called e-democracy basing on the application of information and communication technology (Czajkowski, Kaczmarczyk, 2001, p. 48).

One should remember that next to e-democracy, a very important element of this consideration is the concept of electronic participation, which is understood as "the use of ICTs to support information provision and 'top-down' engagement, i.e. government-led initiatives, or 'ground-up' efforts to empower citizens, civil society organisations and other democratically constituted groups to gain the support of their elected representa- 
tives. Effective information provision is often seen as a corollary of effective engagement and empowerment" (Macintoch, Whyte, 2006, p. 2).

There are enumerated three levels of participation in the process of making political decisions: "information (unidirectional information flows, in which governments produce and deliver information for use by citizens), consultation (in which citizens provide feedback on policy issues identified by government), and participation (in which citizens themselves partly define the process and content of policy making)" (Komito, 2005, p. 39). It's been stated that the modern technologies have potential to be a mechanism for greater and more effective political participation of those with political rights, which is related to the open access to greater amounts of information that enables citizens to engage and participate in policy formation more effectively (Dutton, 1996, 1999; Komito, 2005, p. 39-40).

The application of modern technologies in democratic government is undoubtedly a certain type of a novelty - not only from the perspective of political institutions, parties, politicians or even mass media, but also from the perspective of the electorate. With the availability of new (apart from traditional) forms of participation, such as electronic community consultations, people's electronic initiatives, participatory budgeting, KoNET, e-voting, the citizens are offered the possibility to increase their activity on the political scene and their real influence on the decision-making process. The experiences of numerous European countries (Estonia, Switzerland, Norway, Great Britain) show additional "new, ICT-aided" participation tools help reduce the distance between politicians and voters, which is in turn, in the context of a crisis in democracy.

The opportunities created by e-participation tools give hope for counteracting such problems of contemporary democracy as lack of trust for the government, faint interest in politics and low level of active citizenship. On the other hand, however, such solutions are occasionally criticized by the Polish political class. E-participation opponents point to various risks related e.g. to netcrime, manipulation or even the possibility of distorting election results. A separate issue is also the problem of network accessibility for the citizens (e-exclusion) or broadly defined media education related to the use of new technologies in everyday life, including political participation.

\section{Electronic voting}

Electronic democracy can be examined in terms of political market (a communication space in which political parties and institutions inform electorate about their activities through mass media), which includes three main sets of people (the first group - political and public organizations; second - electorate, third - mass media) (Cichosz, 2002, p. 91, 93).

Taking into account the structure of the market enables to graphically represent the influence of the Internet on relations and processes of political market.

Diagram 2. shows three processes that occur on political market: informing, communicating and voting. Besides their traditional dimension (illustrated with solid arrows), the development of new technologies contributed to the emergence of new ways of communication, information and voting (illustrated with dotted arrows). ICT, and most of all, 
the Internet influence democratic processes, thus supplement, quicken and facilitate three various types of activities: sharing information, involvement in political debate and participation in decision-making political processes (Tsagarousianou, 1999, p. 189-208).

The first process on political market is information. Public institutions generate enormous amounts of information, which can be quickly delivered to citizens through ICT (for example, through the Internet). Enabling society to access information online (without a need to leave home and travel to a given institution, without a need to wait in queues) is a revolutionary progress seen from the citizen's point of view (the citizen, who previously had to use traditional ways of inquiring information which often included long bureaucratic procedures).

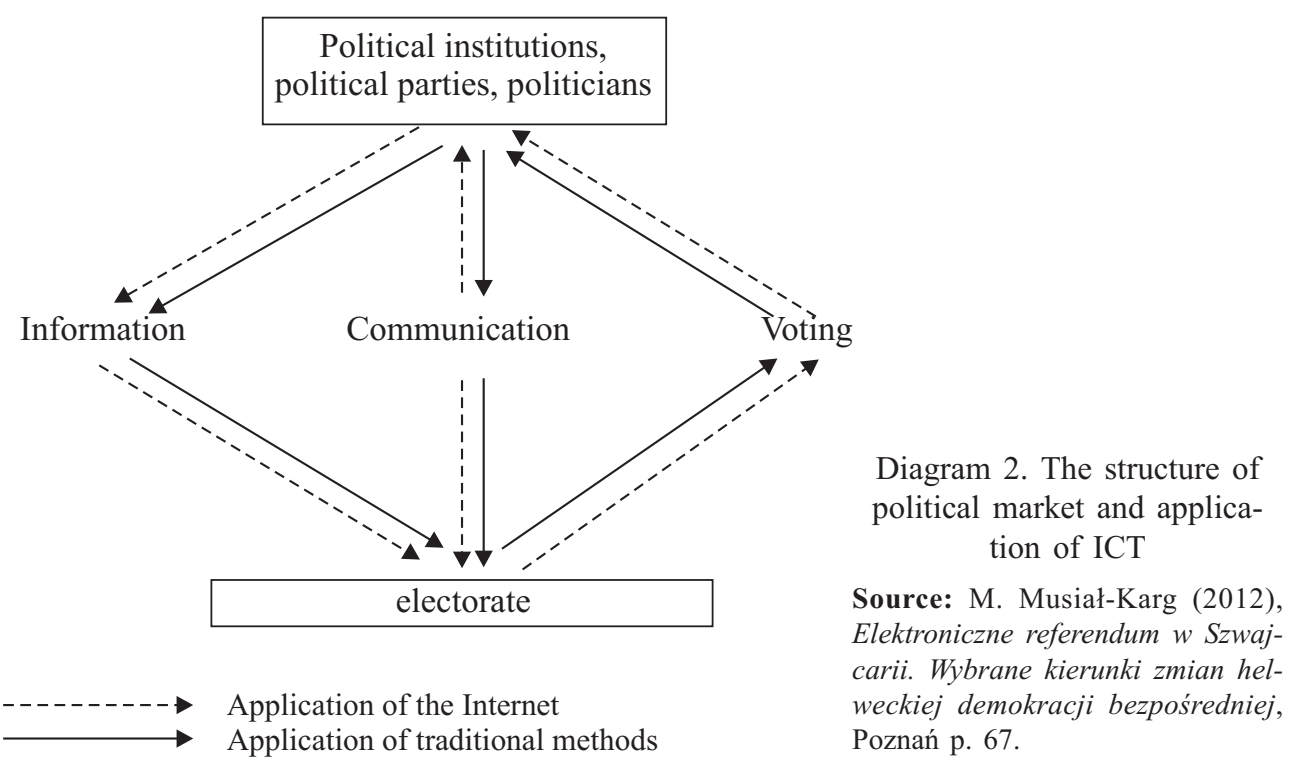

ICT are also used in the process of communication between politicians and voters. It seems both political parties and politicians themselves have recently appreciated many ICT forms (in particular, the Internet) for the possibility they provide to exchange views with the electorate. Thanks to that, one may say that ICT have become important elements reducing the distance between citizens and political elites.

The third process on political market is voting. One of the biggest advantages of applying ICT is that electronic democracy has a potential to overcome barriers, which hinder or limit the electorate to participation in direct decision-making processes. Electronic voting is the subject of interest of public institutions, political parties and politicians. It's being researched, pilot studied and a subject of trade agreements. E-voting seems to be gaining more and more importance and is beginning to be one of the primary instruments of e-democracy.

Many researchers working on the problems of applying new technologies in decision-making processes claim that in the future citizen's rights and duties will be realized with the use of an infrastructure based on ICT. The essential element of such expansion would be the electronic voting, which is currently being implemented in some countries. 
According to the definition by Czajkowski i Kaczmarczyk "electronic voting [...] is the act of voting with the use of electronic means. Electronic voting comprises computer voting - which in turn comprises online voting -, and internet voting which requires computer with an access to the Internet" (Czajkowski, Kaczmarczyk, 2001, p. 47, 50)

There is an obvious lack of terminological discipline in literature, with regard to the differentiation between voting forms that use ICT (information and communication technologies). Two types of such voting are usually mentioned: electronic voting (e-voting) and Internet voting ( $i$-voting).

E-voting is a term of broader meaning, and internet voting is just one of its forms. Electronic voting, however, refers to technologies that are used within voting processes such as: digital broadcasting, telephony, the Internet. (Nowina-Konopka, 2006, p. 2) Internet voting is divided into two categories: Internet Voting at the Polling Place (voting is conducted in a previously prepared place that has a connection to the Internet) and $R e$ mote Internet Voting (remote way of voting which enables a voter to vote from a "voting booth" or through a home PC that is connected to the Internet. Data both from a booth and a PC are transmitted online to a central database) (Musiał-Karg 2012, p. 72-78).

\section{E-voting - experiences of European countries}

Enabling citizens to vote and decide directly about important matters, which concern their society and condition of their country is the heart of democracy (Grabowska, 2005, p. 18). Even though societies widely apply information and communication technologies into business, work or education, governments and legislative bodies in many countries are still self-restraint with using ICT in voting procedures. What is more, one of the reasons for delays in introducing advanced voting technologies is almost unanimous carefulness among societies of information sciences regarding the so-called Internet-based elections (O’Hanlon, 2006, p. 16-23). Many countries resigned from $e$-voting because they found it to risky. Other nations don't seem to realize the advantages of electronic voting over traditional way of election - by ballot boxes.

Since 1990s, when the rapid development of the Internet began, more and more politicians, scientists or journalists have been wondering whether electronic voting (especially Internet voting) is a good solution for general elections or referenda. The governments of numerous European countries, many scientific initiatives world-wide and non-governmental organizations try to launch solutions based on application of ICT and introduce them into key democratic processes, such as voting. Fortunately for the supporters of electronic voting, more and more countries in the world are beginning to consider e-voting systems useful or actually are implementing them. It is, however, worth remembering that most of attempts are still at the testing or conceptual stage.

Globally speaking, the undisputed leader among countries which introduced e-voting systems are the United States where electronic voting that use special equipment with touch-screens is very popular. Voting done in this way shortens polling procedures and, according to the information acquired from vendors of touch-screen machines, considerably lower the costs of election (Zetter, 2008). Introduction of electronic voting in the United States is associated with president William J. Clinton's and vice-president Albert 
Gore's administrative politics. Both men decided that one of the most important goals of their activities will be to implement systems for electronic voting and electronic democracy (Nowina-Konopka, 2006, p. 9). The first electronic election was held on March 11, 2000 in the state of Arizona where a Democratic Party candidate for the post of president of the USA was selected. Despite the difficulties encountered in the course of election, over 17 thousand democrats in Arizona state gave their votes through the Internet just on the first two days of early online election. During the election in 2008, registered voters in Arizona who lived abroad had an opportunity to vote over the Internet thanks to a new system offered by the local secretary of state (Arizona offers military online voting).

Table 1

Application of electronic voting in the European countries (selected votings)

\begin{tabular}{|l|l|c||}
\hline \multicolumn{1}{|c|}{ Country } & \multicolumn{1}{|c||}{ Application of e-voting } & Time \\
\hline Austria & Test Election for Austrians living abroad & $12-14.10 .2006$ \\
\hline Belgium & Voting machines-tests & No date \\
\hline Bulgaria & Town Council E-Voting of Kazanluk & 7.05 .2008 \\
\hline Estonia & Municipal elections & $10-12.10 .2005$ \\
\hline Estonia & Parliamentary elections & $26-28.02 .2007$ \\
\hline Finland & E-voting in local elections in Karkkila, Kaunianien, Vihti & 10.2008 \\
\hline Italy & Administration elections - Autonomous Province of Trento & 8.05 .2005 \\
\hline Netherlands & Parliamentary elections - Lower House & $18-22.11 .2006$ \\
\hline Portugal & Parliamentary General Elections - Voters Abroad & 20.02 .2005 \\
\hline Portugal & Elections for the European Parliament & 06.2004 \\
\hline Spain & Referendum “Constitution for Europe” - 53 municipalities & $1-18.02 .2005$ \\
\hline Great Britain & Local elections (Liverpool, Sheffield...) & $2003,2005,2007$ \\
\hline Switzerland & Neuenburg, Zurich, Geneva (February 2009 Constitution) & from 2001-...test voting \\
\hline
\end{tabular}

Source: Competence Center for Electronic Voting and Participation (E-Voting.CC).

Not only in the United States, but also in many European countries, new voting technologies have been implemented or their implementation is in progress. Attempts to implement the so-called e-voting lead to various effects in different countries (Table 1).

On the local level, electronic voting with the Internet, text messages and with the use of modified interactive POS and smart cards (which were used to identify voters in a POS) was first introduced in spring 2002 in Great Britain, in two electoral districts in Liverpool and three in Sheffield (where the smart cards to identify voters in a POS were used). Apart from electronic voting, there was a possibility to vote traditionally in polling stations or send correctly filled voting papers through post. Traditional votes were counted electronically with the use of special bar codes. $40 \%$ of voters in Liverpool and about $30 \%$ of voters in Sheffield chose to vote electronically. In total, almost 5 thousand people decided to use e-voting method (Czerniejewski, 2002).

The most successful attempts to introduce e-voting are associated with the electronic voting systems from Switzerland and Estonia. In Switzerland, the implementation of three pilot voting projects was considered already in the year 2000 . The projects included 
cities of Geneva, Zurich and Neuchâtel. Firstly, a federal decision was made, then communes and cantons were supposed to individually decide about the project. The projects took into consideration various application of new technologies. They enabled voting in elections and referenda e.g. with the use of the Internet or text messages. In 2005 the projects were evaluated and between 2006 and 2007 parliaments were to decide whether one of the projects would be implemented or not. Apart from Switzerland, electronic voting has also been introduced in some of the states in the USA.

The second most popular European example of electronic voting introduction is Estonia, which happened to be the first country in the world that conducted binding internet voting - the whole electorate of this small European country had a possibility to vote over the Internet. Binding internet voting was carried out there seven times: in local elections $(2005,2009,2013)$, in parliamentary elections $(2007,2011)$, and in European Parliament Elections $(2009,2014)$. The most important reasons for introducing additional manner of voting in Estonia are : to make an additional and convenient voting channel available and consequently to update voting procedures, as well as enabling a more efficient use of infrastructure (digital platforms and electronic IDs). Estonian e-voting system differs then from Swiss projects. In order to vote through the Internet, a voter needs: electronic identity card (eID) with valid certificates (renewed at a webpage), PIN numbers (issued together with eID cards) and a computer with eID card reader (plus appropriate software available at installer.id.ee/), Internet connection and one of the following operating systems installed: Windows, MacOS, Linux (Estonian National Electoral Committee).

Table 2 presents the results of Internet voting in parliamentary election (2011), in municipal elections (2013), and elections to the European Parliament in Estonia. The analysis of data suggests that the interest in the new way of participation in voting procedures rises systematically, which suggests that the citizens find this method of voting very comfortable and effective. It needs to be pointed out that the Internet voter turnout increased from about $1 \%$ in 2005 to $11,4 \%$ in 2014 .

Table 2

Internet voting in recent Estonian elections of 2011, 2013 and 2014

\begin{tabular}{|l|c|c|c||}
\hline & $\begin{array}{c}\text { Parliamentary elec- } \\
\text { tions, 2011 }\end{array}$ & $\begin{array}{c}\text { Local elections, } \\
\mathbf{2 0 1 3}\end{array}$ & EP elections, 2014 \\
\hline Eligible voters & 913,346 & $1,086,935$ & 902,873 \\
\hline voter turnout & $63.5 \%$ & $58.0 \%$ & $36.5 \%$ \\
\hline I-voters among eligible voters & $15.4 \%$ & $12.3 \%$ & $11.4 \%$ \\
\hline I-voters among participating voters & $24.3 \%$ & $21.2 \%$ & $31.3 \%$ \\
\hline
\end{tabular}

Source: Estonian National Electoral Committee, http://www.vvk.ee/voting-methods-in-estonia/engindex/statistics/, 11.12.2014.

The researches on applications and efficiency of $i$-voting in Estonia report that Estonians' attitude towards this new form of voting was and still is positive, and the decision to seize the opportunity to i-vote seem to be dependent on confidence in the new method, not - as it was previously expected - on political influences. 


\section{Conclusion}

One of the most important tools of e-democracy is electronic voting. Recent years prove that interest in implementation of new forms of civil participation - e-voting - increases systematically, especially in Europe. It is confirmed by various pilot projects introduced in greater and greater number of countries whose parliaments consider the idea of electronic voting implementation. Motives for $e$-voting implementation are various, and the most frequent reasons are as follows: increasing voters' mobility, enabling voters who live outside their home country to participate in elections, increasing voter turnout by providing additional platform for voting, extending access to democratic procedures for the sick and disabled people, decreasing costs of elections, publishing election results in an independent and much quicker way (Remmert, 2004, p. 13-16). Whereas the first four reasons carry undeniable profits for voters with regard to their comfort and participation, the two last reasons are connected with reduction of the administrative expenses. Electronic voting is thus helpful not only in procedures of vote counting, but also supports the three main processes in a voting itself: pre-election stage (identification of electorate), election stage (voting) and post-election stage (counting of votes). Despite current apparent problems concerning worries about safe and secure elections etc., positive experience of increasingly higher number of European countries may act as a spur to implementation of e-voting not only in the rest of European nations, but also in many countries all over the world.

Summing up, it should be emphasized that together with a highly dynamic development of modern technologies and their increasingly common application to political space, there is a need for conducting thorough researches into current experiences and future possibilities of supporting political participation among the citizens with electronic tools, particularly e-voting, which is attracting more and more attention of politicians and voters.

\section{References}

Arizona offers military online voting, FederalComputerWeek, September 30, 2008, http://www.fcw.com/ online/news/153948-1.html, 11.11.2008.

Braun N., Brändli D. (2006), Swiss E-Voting Pilot Projects: Evaluation, Situation Analysis and How to Proceed, in: Electronic Voting 2006. $2^{\text {nd }}$ International Workshop Co-organized by Council of Europe, ESF TED, IFIPWG8.5 and E-Voting.CC August, $2^{\text {nd }}-4^{\text {th }}, 2006$ in Castle Hofen, Bregenz, Austria, ed. R. Krimmer, Gesellschaft für Informatik Bonn.

Browning G. (2005), Electronic Democracy. Rusing the Internet to Transform American Politics, Information Today Inc., Bedford-New Jersey.

Cichosz M. (2002), Metody analizy i diagnostyki rynku politycznego, in: A. Jabłoński, L. Sobkowiak, Marketing polityczny w teorii i praktyce, Wydawnictwo Uniwersystetu Wrocławskiego, Wrocław.

Czajkowski R., Kaczmarczyk A. (2001), E-Głosowanie-niezbędny element elektronicznej platformy do obstugi procedur w demokracji w spoleczeństwie informacyjnym. E-vote-an essential element of electronic platform for services for democratic procedures in the Information Society, referate presented during a conference "Tworzenie mechanizmów i struktur rozwoju elektronicznej gospodarki w Polsce”, Warsaw, 12.06.2001, pp. 47-57. 
Czerniejewski B. (2002), Królewska e-władza. UK online, "Pckurier”, no. 13, http://www.pckurier.pl/ archiwum/art0.asp?ID=5549, 22.11.2008.

Drechsler W., Madise Ü. (2006), Electronic Voting in Estonia, in: Electronic Voting and Democracy. A Comparative Analysis, Palgrave Macmillan, Basingstoke.

Dutton W. H. (1999), Society on the line: information politics in the digital age, Oxford University Press, Oxford.

Dutton W. H. (ed.), (1996), Information and communication technologies - visions and realities, Oxford University Press, Oxford.

Electronic Voting 2006. $2^{\text {nd }}$ International Workshop Co-organized by Council of Europe, ESF TED, IFIP WG 8.5 and E-Voting.CC August, $2^{\text {nd }}-4^{\text {th }}, 2006$ in Castle Hofen, Bregenz, Austria, ed. R. Krimmer, Gesellschaft für Informatik, Bonn 2006.

Estonian National Electoral Committee, http://www.vvk.ee/, 11.12.2014.

Gawrysiak P. (2008), Cyfrowa rewolucja. Rozwój cywilizacji informacyjnej, Wydawnictwo Naukowe PWN, Warszawa.

Grabowska S. (2005), Instytucja ogólnokrajowej inicjatywy ludowej w wybranych państwach europejskich. Studium prawno-porównawcze, Wydawnictwo Uniwersytetu Rzeszowskiego, Rzeszów.

Grossman L. K. (1995), The Electronic Republic. Reshaping Democracy in the Information Age, Viking, New York.

Hacker K. L., Todino M. (1996), Virtual Democracy at the Clinton White House: An Experiment in Electronic Democratisation, javnost/the public, vol. 3, no. 1, pp. 71-88.

Hagen M. (1997), A Typology of Electronic Democracy, http://www.uni-giessen.de/fb03/vinci/labore/netz/hag_en.htm, 12.04.2014.

Hague B. N., Loader B. (1999), Digital Democracy: Discourse and Decision-making in the Information Age, Routledge, New York.

Kaczmarczyk A. (2010), Cyberdemocracy. Change of Democratic Paradigm in the $21^{\text {st }}$ Century, Key Publishing House, Toronto.

Keohane R. O., Nye jr J. (1999), Power and Interdependence in the Information Age, in: E. Kamarck, J. Nye jr, Democracy.com? Governence in a Networked World, Hollis Publishing, Holis.

Komito L. (2005), e-Participation and Governance: Widening the net, "The Electronic Journal of e-Government", vol. 3, Issue 1, pp. 39-48.

Krimmer R., Schuster R. (2008), The E-Voting ReadinessIndex, in: Electronic Voting 2008 (EVOTE08), $3^{r d}$ International Conference Co-organized by Council of Europe, Gesellschaft für Informatik and E-Voting.CC August $6^{\text {th }}-9^{\text {th }}, 2008$, in Castle Hofen, Bregenz, Austria, eds. R. Krimmer, R. Grimm, Gesellschaft für Informatik e.V. (GI), Bonn.

Lakomy M. (2013), Demokracja 2.0. Interakcja polityczna w nowych mediach, WAM, Kraków.

Macintoch A., Whyte A. (2006), Evaluating how eparticipation changes local democracy, eGovernment Workshop '06 (eGOV06) September 11, 2006, Brunel University, West London.

Madise Ü., Martens T. (2006), E-voting in Estonia 2005. The first practice of country-wide binding Internet voting in the world, in: Electronic Voting 2006. $2^{\text {nd }}$ International Workshop Co-organized by Council of Europe, ESF TED, IFIP WG 8.5 and E-Voting.CC, August, $2^{\text {nd }}-4^{\text {th }}$, 2006 in Castle Hofen, Bregenz, Austria, ed. R. Krimmer, Gesellschaft für Informati, Bonn.

Maj P. (2009), Internet i demokracja. Ewolucja systemu politycznego, Wydawnictwo Uniwersytetu Rzeszowskiego, Rzeszów.

Marczewska-Rytko M. (2002), Demokracja bezpośrednia w teorii i praktyce politycznej, UMCS, Lublin.

Marczewska-Rytko M. (2010), Idea demokracji bezpośredniej od okresu antycznego do czasów Internetu i globalizacji, in: Demokracja bezpośrednia. Wymiar globalny lokalny, eds. M. Marczewska-Rytko, A. K. Piasecki, UMSC, Lublin 2010. 
Mider D. (2008), Partycypacja polityczna w Internecie. Studium politologiczne, Dom Wydawniczy Elipsa, Warszawa.

Musiał-Karg M. (2012), Elektroniczne referendum w Szwajcarii. Wybrane kierunki zmian helweckiej demokracji bezpośredniej, WNPiD UAM, Poznań.

Musiał-Karg M. (2010), Gtosowanie elektroniczne - nowe wyzwanie dla demokracji?, "Przegląd Politologiczny", no. 4.

Musiał-Karg M. (2011), The Theory and Practice of Online Voting. The Case of Estonia (selected issues), "Athenaeum. Polish Political Science Studies", no. 29.

Nowina-Konopka M. (2006), Elektroniczna urna, http://www.rpo.gov.pl/pliki/12066058070.pdf, 27.11.2008.

O'Hanlon Ch. (2006), A Conversation with Douglas W. Jones and Peter G. Neumann, Queue 4, (Nov. 2006), pp. 16-23, http://queue.acm.org/detail.cfm?id=1180188, 30.06.2012.

Porębski L. (2004), Elektroniczne oblicze polityki. Demokracja, państwo, instytucje polityczne w okresie rewolucji informacyjnej, AGH Uczelniane Wydawnictwo Naukowo-Dydaktyczne, Kraków.

Porębski L. (2012), Lokalny wymiar elektronicznej demokracji, Wydawnictwo Akademickie, Kraków.

The European Union and E-Voting. Addressing the European Parliament's Internet Voting Challenge, ed. A. H. Trechsel, F. Mendes, Routledge, New York 2005.

Trechsel A. H., Mendez F., Kies R. (2002), Remote voting via the Internet? The canton of Geneva pilot-project, in: Secure Electronic Voting, ed. D. Gritzalis, Kluwer Academic Publishers.

Trechsel A. H. (2007), E-voting and Electoral Participation, in: Dynamics of Referendum Campaigns, An International Perspective, ed. C. de Vreese, Palgrave, London

Tsagarousianou R. (1999), Electronic democracy: Rhetoric and reality, "Communications: The European Journal of Communication Research", vol. 24, no. 2, pp. 189-208.

Tsagarousianou R. (2000), Electronic Democracy in Practice: One, Two, Three... Countless Variants, "HERMÈS", no. 26-27.

Zetter K. (2008), The Cost of E-Voting, "Wired.com", 11.11.2008.

\section{Zastosowanie e-głosowania jako nowego narzędzia e-partycypacji we wspólczesnej demokracji}

\section{Streszczenie}

Znalezienie odpowiedzi na pytanie o rolę elektronicznego głosowania w elekcjach państwowych stanowi ważną część badań nad demokracją elektroniczną. W wyniku dynamicznego rozwoju technologii informacyjnych i komunikacyjnych (ICT) doszło do zauważalnych zmian w funkcjonowaniu współczesnych państw i społeczeństw. ICT zaczynają odgrywać większą rolę, przenikając niemal każdą dziedzinę życia współczesnego człowieka - także politykę. Elektroniczne głosowanie stanowi jedną z coraz bardziej popularnych form tzw. e-demokracji, i staje się interesującym przedmiotem badań. Głównym zagadnieniem niniejszego tekstu jest wykorzystanie głosowania elektronicznego (e-głosowania) jako jednej z form demokracji elektronicznej. Artykuł stanowi próbę odpowiedzi na następujące pytania badawcze: po pierwsze, jak ICT wpływają na procesy polityczne - szczególnie na procedury głosowania? Po drugie, co jest istotą głosowania elektronicznego i jakie są jego główne cechy? Wreszcie, jakie doświadczenia z e-głosowaniem mają państwa europejskie? Tekst nie stanowi wyczerpującej analizy przedmiotu badań. Ma być raczej przyczynkiem do dalszych rozważań nad e-demokracją e-partycypacją, a przede wszystkim e-głosowaniem.

Słowa kluczowe: e-głosowania, głosowanie elektroniczne, e-demokracja, TIK 